\title{
Effects of parent material on soil erosion within Mediterranean new vineyard
} plantations

\author{
Jesús Rodrigo-Comino ${ }^{1}$, Agata Novara ${ }^{2}$, Yeboah Gyasi-Agyei ${ }^{3}$, \\ Enric Terol ${ }^{4}$, Artemi Cerdà
}

(1) Instituto de Geomorfología y Suelos, Department of Geography, University of Málaga, Edificio Ada Byron, Ampliación del Campus de Teatinos, 29071, Málaga, Spain.

(2) Dipartimento di Scienze Agrarie, Alimentari e Forestali, University of Palermo, viale delle scienze. Italy.

(3) School of Engineering and Technology, Central Queensland University, Rockhampton, Australia.

(4) Department of Cartographic Engineering, Geodesy and Photogrammetry, Universitat Politècnica de València, Camino de Vera, s/n, 46022 Valencia, Spain.

(5) Soil Erosion and Degradation Research Group, Department of Geography. Universitat de València, Blasco Ibañez, 28, 46010 Valencia, Spain.

Corresponding author: Jesús Rodrigo-Comino (rodrigo-comino@uma.es) 


\section{ABSTRACT}

Parent material can determine specific physical and chemical soil properties and, therefore, soil erosion rates. However, for new vine plantations, there is not enough research on soil erosion assessment on different parent materials which could be helpful for agricultural management plans. The main aim of this research was to quantify soil erosion rates of two recent vineyard plantations under similar climate and land use management conditions, but on different parent materials, namely colluvium (2 years old) and marls (8 years old), located within the Les Alcusses valley vineyards in Eastern Spain. To achieve this goal, the ISUM (improved stock unearthing method) was applied. ISUM involves measurements of vertical distances from a horizontally stretched meter band attached to opposite pair vine plants to the topsoil surface at 5 sampling points along the cross sections of the pair vine rows. The original surface level was determined from the fixed distance of $2 \mathrm{~cm}$ of the graft unions from the soil surface. Digital elevation modelling of the vertical measurements was used to infer the erosion rates. Annual total soil erosion rates were $87.7 \mathrm{Mg} \mathrm{ha}^{-1} \mathrm{yr}^{-1}$ and $4.35 \mathrm{Mg} \mathrm{ha}^{-1} \mathrm{yr}^{-}$ 1

in the marls and colluvium plots, respectively. For the marls plot, 67\% of the depletion occurred in the inter-row areas, whereas for the colluvium plot the inter-row areas registered $4.78 \mathrm{Mg} \mathrm{ha}^{-1} \mathrm{yr}^{-1}$ depletion and the row areas showed only a deposition of $0.44 \mathrm{Mg} \mathrm{ha}^{-1} \mathrm{yr}^{-1}$. We hypothesised that the inter-row areas registered the highest erosion rates due to the tillage practices. In the row areas, the cover of the vines possibly reduced soil erosion rates and acted as sinks for sediments. This behaviour of the interrow areas acting as sources and the row areas as sinks for sediments was more evident on the colluvium plot, while most sections on the marls plot showed intense erosion features. It is suggested that more attention should be paid by policymakers and stakeholders to these differences when new plantations are introduced on marls and 
colluvium vineyards. We claim that initial soil erosion control measures should be applied during the first few years of plantations instead of when the vineyards are much older and soil has already been mobilised.

KEY WORDS: soil erosion; recent plantations; parent material; vineyards; ISUM. 


\section{INTRODUCTION}

Parent material is a key factor that determines the main physical and chemical properties of a soil (Chesworth, 1973; Osher and Buol, 1998). Soil scientists have accepted this fact as a universal law. Notable examples of soil scientists who have paid attention to the effects of the parent material on soil properties include Brimhall et al. (1991), Driese et al. (2003), Muhs et al. (2001), Rawlins et al. (2003) and Yesilonis et al. (2008). Within the Earth Sciences, the effect of parent material on soil processes was confirmed when a holistic view was applied by means of the biochemical cycle approach (Anderson, 1988).

It is well-known that soil formation is a consequence of the weathering of the rocks, the decomposition of the organic matter and the turnover of the materials, minerals, water, organic matter, air and life, which result in the horizon formation (Wagai et al., 2008; Duchaufour, 1997; Fitzpatrick, 1980; Chesworth, 1973). Moreover, some specific soil degradation phenomena occur in connection with certain parent materials due to the abundance of other environmental and anthropogenic factors which reduce soil depths, organic matter, biota activity, water retention capacity, and fertility (Orgill et al., 2017).

Soil erosion is a key process that determines the soil fate in natural ecosystems, and parent material again plays a key role as it determines soil erosion processes and rates (Cerdà, 1999, 2002), soil erodibility, surface topography and landforms (Bryan et al., 1989; Bryan, 2000). However, little attention has been paid to other topics such as the biotic (mainly plants' effects on soil erosion), hydric (rainfall and runoff effect on sediment delivery), soil properties and land management impact on soil erosion in relation to the parent material and the age of plantation. 
This brief description of the state-of-the-art underscores the importance of parent material on soil processes. However, there is little research on the effects of parent material on soil erosion (Mohammadkhan et al., 2011; Pennock et al., 1995; Weaver, 1991), the evolution of the biological properties (Braithwaite et al., 1984; Ulrich and Becker, 2006) and availability of nutrients (Yavitt, 2000; Yesilonis et al., 2008). The role that parent materials play in soil erosion is also relevant to understanding the fate of the soils, their formation, and degradation (Nazari Samani et al., 2016; Orgill et al., 2017). Therefore, the need for researching the role of parent materials on soil erosion and other associated processes cannot be overstated.

The importance of parent material is especially relevant on bare soils devoid of protective vegetation cover such as in recently afforested areas and planted orchards (Corti et al., 2011). The lack of vegetation allows the parent material to be a driving factor of soil erosion (Atucha et al., 2013; Lombardi et al., 2017). This is very relevant in agricultural land such as vineyards, where the lack of vegetation due to tillage and the use of herbicides results in high erosion rates that are dependent on the parent material type. It is noted that the soil horizon development and soil biomass composition are highly dependent on soil formation and degradation processes (Cattanio, 2017; Foltz et al., 2011). Among the degradation processes, soil erosion is the severest threat as it removes soil mass. In agricultural lands, and specifically in conventional vineyards with partially bare soils in young plantations, the impact of parent material on soil erosion is highly relevant due to low vegetative cover and low root development, but it is in many instances ignored. Recently, the negative impact of the age of plantations has been highlighted, but only the parent material was mentioned with little information on age (Rodrigo-Comino et al, 2018a; Cerdà et al., 2017). Another key factor studied at great lengths in the literature is the control that vegetation exerts on soil erosion (Martínez- 
Casasnovas et al., 2009). The vegetation cover and the age of plantation is highly controlled by the climate but also influenced by human activities such as agriculture. Different land management strategies have been widely investigated during the last decade though (Berland et al., 2017; Dawson et al., 2017).

In European vineyards, where intensive tillage with machinery (Arnaez et al., 2007) or herbicide applications (Salomé et al., 2016) have resulted in bare soils, the parent material has become one of the most relevant key factors of terroir characterisation (Vaudour, 2002; Vaudour et al., 2015), but its effect on different lithological groups has not been highlighted. Within Mediterranean vineyards, soil erosion has been studied in facies such as sedimentary (Quiquerez et al, 2008, Martínez-Casasnovas et al., 2009) and metamorphic materials (Biddoccu et al., 2017a) with bare soils. All tested soils demonstrated that vegetation cover reduces the soil and water losses to some degree depending on the percentage cover. However, long-term monitoring at the pedon scale of the influence of the parent material on soil erosion rates in new plantations is rare.

The main goal of this research is to quantify soil mobilisation rates and microtopographical changes on two different parent materials (colluvium and marls) within two vineyards using the improved stock unearthing method (ISUM). We intend to demonstrate the impacts of age of plantations under the same land use management and climate conditions on erosion.

Although, water erosion is commonly observed on steeper slopes (slope angles > $16^{\circ}$ ) rather than on conventional mild slope terraces (slope angle $<5^{\circ}$ ), previous research showed that intense ploughing, use of pesticides, herbicides and fungicides, and extreme rainfall events can cause high soil erosion rates in vineyards of both mild and steep slope terraces (Ramos and Porta, 1997, slope angles $>16^{\circ}$; Sofia and Tarolli, 
2017, slope angles $2^{\circ}-9^{\circ}$ ). Therefore, we decided to conduct our research in two conventional vineyards at the Les Alcusses valley, in Eastern Spain, that contain small terraces with moderate slopes supported by long rows of plants. We hypothesise that, although both plots of different ages are producing high amounts of grapes, the degradation processes on the older plot are increased due to erosion. Therefore, the identification of a little-known driving factor of soil erosion, namely the age of plantations or different parent material, may be useful for the development of nature based-solutions and land management plans.

\section{MATERIALS AND METHODS}

\subsection{Study area}

Spain is one of the largest wine producers in the world, and the vineyard management practice is predominantly based on tillage which results in high erosion rates (Marques et al., 2015; Martínez-Casasnovas et al., 2010). We selected an area located in the Eastern Iberian Peninsula that is representative of the vineyards in Spain (Fig. 1). The two chosen experimental paired-plots are situated in the Les Alcusses valley within the Moixent municipality. These areas belong to the traditional viticulture region of the Terres dels Alforins Valencia province. The climate is typically Mediterranean, characterised by warm to hot dry months between June and September. The average total annual rainfall is $350 \mathrm{~mm} \mathrm{yr}^{-1}$ and the average annual temperature is about $13.8^{\circ} \mathrm{C}$. Extreme rainfall intensities higher than $200 \mathrm{~mm} \mathrm{~d}^{-1}$ have been reported during autumn (Castillo and Ruiz Beltrán, 1979).

The first studied plot, having slope angles lower than $5^{\circ}$ because of the terracing (Fig. 1a), belongs to José Molla Frances and Pablo Calatayud and was planted with Pedro Ximénez grape variety eight years before the measurements that took place in 
February 2017. With the plot length of $115.5 \mathrm{~m}$, an inter-row distance of $2.5 \mathrm{~m}$, and inter-plant distance of $1.5 \mathrm{~m}$, each vine row bordering the plot has 77 plants. The plot is placed on lithological facie of marly rocks that come from the Tap facies rich in swelling clays, white in colour, and highly erodible. Also, the Tap facies sediments are rich in calcium carbonate $(70 \%)$. The soil texture can be classified as clay and, also, described as Terric Calcic Anthrosols (IUSS Working Group WRB, 2014).

The second plot (Fig. 1b) is in a vineyard that is part of the Celler del Roure winery which belongs to Pablo Calatayud and was planted with Monastrell grape variety. In developing the plantation, the soil was levelled and the vines were situated in relatively flat micro-terraces. The plantation framework is characterised by $3.0 \mathrm{~m}$ interrow distance and $0.75 \mathrm{~m}$ inter-plant distance. Thus, the tested plot length of $57.8 \mathrm{~m}$ has 77 plants per row, and its inclination is also lower than $5^{\circ}$. The Celler del Roure plot is placed on a footslope of lithological facie of colluvium from limestones, sandstones and dolomitic materials of the Serra Grossa Range. The soil texture is clay loam, being classified as Terric Anthrosols with colluvic materials (IUSS Working Group WRB, 2014). Table 1 presents more information on the soil properties of the two plots, noting in particular that measurements were taken two years after the plantation commenced on the Celler del Roure plot. Soil samples were collected from both plots with seven repetitions along the inter-row and row areas within $0-10 \mathrm{~cm}$ soil depths.

Before the plantation activities began in both plots, all the cultivated fields were levelled and flattened in the form of terraces and the vines were planted into flat and smooth terrains (slope angles $<5^{\circ}$ ). Several tractor passes were performed during the first year to plough the soil and to prepare it before the hand planting of the vines. Therefore, after planting, topsoil compaction signals up to $15 \mathrm{~cm}$ depth were visible in both areas. At some locations, weakly and moderately cemented soils could also be 
noted because of the carbonates. After the planting, tillage was carried out with a tractor that tilled the soil to a depth of about $25 \mathrm{~cm}$, redistributing the material from the inter-row areas to the row areas in the same direction. The soil surfaces were devoid of vegetative cover except underneath the vines. The tractor passes were conducted along the inter-row, which means along the contour line directions perpendicular to the slope direction.

\subsection{Improved stock unearthing method (ISUM)}

The stock unearthing method (SUM) is based on the measurements of the vertical distance between frontal marks on the graft union (visible on grape vines) and the actual topsoil level. At the graft union, unearthed or buried signals register the initial point that signifies the distance from the vine stock to the actual soil surface of the plantation at the time that the observation was taken. As other authors observed (Brenot et al., 2006; Biddoccu et al., 2017b), the distance of the graft union in relation to the original soil surface does not change as a result of plant growth after the vine plantation, thus we could use it as a fixed biomarker. Rodrigo-Comino et al. (2016) also confirmed this in German vineyards, by taking measurements each year over a period of three years in recent plantations, where only the new vine's part corresponding to the grafted grape variety grew. Thus, possible new changes from the initial conditions due to depletion or accumulation could be recorded. The initial distance was constant from the grafting point to the original topsoil level, about $2 \mathrm{~cm}$ with a non-significant uncertainty (within $\mathrm{mm}$ ) to avoid the effect from soil moisture, freezing or fungus. This information was obtained from the farmers by interview and confirmed with recent vineyard plantations' observations in the same area.

It is important to remark that a major weakness of the methodological procedure is the assumption of almost flat topsoil surface. This assumption does not account for 
roughness related to rills, footpaths and wheel tracks (Brenot et al., 2008; Casalí et al., 2009). Therefore, we measured 5 locations along the cross-section of the opposite pair plants located on the two bordering rows; at each of the vine stock graft unions, $0.5 \mathrm{~m}$ and $1 \mathrm{~m}$ from the vine stock graft unions, respectively, for the marls and for colluvium plots, and one at the middle of the cross section as indicated in Fig. 2 (and also in Suppl. Material 1). Thus, 385 (77 x 5) measuring points were sampled for each plot. A meter band was stretched to join the opposite pair graft unions of the two bordering vine rows. The meter band was placed $30 \mathrm{~cm}$ above each paired-vine plant to allow measuring buried vine stocks (positive measures) and unearthed ones (negative measures). A meter stick was used to measure the vertical distance between the horizontally stretched meter band and the current soil surface at all sampling points. Using the collected data, DEMs (digital elevation models) were generated in ArcMap 10.5 (ESRI). Linear processes such as rills, sinks, accumulations or connectivity processes were detected. This is an improved version of SUM, the ISUM (improved stock unearthing method).

\subsection{Topsoil level cartography, soil erosion rates and statistical analysis}

To mimic the actual topsoil level on the day of measurements (08/02/2017), point fishnets were generated from the DEMs. The obtained maps were then used to assess topsoil level changes over the plots. The total soil loss $\left(\mathrm{Mg} \mathrm{ha}^{-1} \mathrm{yr}^{-1}\right)$ was estimated from the erosion-deposition (ER) equation of Paroissien et al. (2010):

$\mathrm{ER}=\frac{\operatorname{Vol} \times B D}{\mathrm{~A} \times \mathrm{Av}}$

where $\mathrm{Vol}$ is the volume of soil lost corresponding to the space between the graft union and the current topsoil levels, $A$ is the total area in hectares, Av is the age of the vines (eight years for the marls and two years for the colluvium plots) and BD is the bulk density. Measured BD values were $1.43 \mathrm{~g} \mathrm{~cm}^{-3}$ for the vineyards on marls and $1.05 \mathrm{~g}$ 
$\mathrm{cm}^{-3}$ for the vineyards on colluvium. These results were obtained by sampling with a steel cylinder $\left(100 \mathrm{~cm}^{3}\right)$ from different depths $(0-15 \mathrm{~cm})$ and at seven slope positions. The mean values of $\mathrm{BD}$ at different depths were used as representative of the entire studied plot. More information related to this procedure can be found in RodrigoComino and Cerdà (2018).

The measured points are shown in boxplots (Fig. 2), representing averages (dotted lines), medians (continuous line in the middle of the box) and $5^{\text {th }}$ and $95^{\text {th }}$ percentiles at the ends of the boxes. To compare the results obtained in the 5 inter-row sampling points, a Mann-Whitney Rank Sum Test was performed with Sigma Plot 12.0 (Systat Software Inc.). Neither a normal distribution nor equal variance could be observed in the measured data. This was confirmed by the Shapiro-Wilk test for normality and equal variance test.

\section{RESULTS}

\subsection{Actual topsoil level assessment}

Boxplots showing the averages, median and $5^{\text {th }}$ and $95^{\text {th }}$ percentiles are presented in Fig. 2. Fig. 3 shows the DEM of the actual topsoil level for (a) colluvium and (b) marls using the data collected. In the colluvium (Fig. 3a), the highest depletions were observed in the middle part of the inter-row $(-3.8 \mathrm{~cm}), 1 \mathrm{~m}$ from the left vine stock $(-1.3$ $\mathrm{cm})$ and $1 \mathrm{~m}$ from the right vine stock $(-4.14 \mathrm{~cm})$. The most important erosional features (sinks and rills) that could be observed appeared in the section from $50 \mathrm{~m}$ to $70 \mathrm{~m}$, close to the outlet of the inter-row (warm colours). In general, the soil surface showed a higher topsoil level in the colluvium study site than in the marl one. This can imply that the soil has been better conserved since the vines were planted or be a consequence of the difference in age, colluvium plantation being only 2 years old while the marls 
plantation is 8 years old. The maximum accumulation value was $+12 \mathrm{~cm}$ and the minimum reached $-11 \mathrm{~cm}$.

For the measurements carried out on the marls plantation (Fig. 2b), no soil accumulation zones were found. The highest depletion values were registered in the inter-row sampling points, varying between $-6.2 \mathrm{~cm}$ at $1 \mathrm{~m}$ from the left vine stock and $-5.2 \mathrm{~cm}$ at $1 \mathrm{~m}$ from the right vine stock. In both vine stock measurements, soil depletion was also noted (from -3.7 to $-4.3 \mathrm{~cm}$ ). The maximum positive point measurement values reached $+8 \mathrm{~cm}$ in the row areas and no change in the inter-row areas, while the minimum depletion reached $-19 \mathrm{~cm}$. On the map, the highest average soil depletion can be observed from $10^{\text {th }}$ to $20^{\text {th }}$ (lower end) vine row, and from the middle section $\left(40^{\text {th }}\right.$ vine row) to the upper part $\left(70^{\text {th }}\right.$ vine row), where the warm colours are predominant, showing several sinks and initial linear soil erosion features. Soil accumulation or topsoil level maintenance can be observed only close to the vine stocks, and mainly from the $10^{\text {th }}$ to $30^{\text {th }}$ vine rows.

Comparing the two plots, the statistical analysis (Table 2) showed significant differences at the vine stocks and $1 \mathrm{~m}$ from the left vine stock sampling points $(\mathrm{p}<0.001)$. This is also true when all data from each plot were combined and compared, reaching an average of $3.2 \mathrm{~cm}$. On the contrary, at the middle inter-row sampling points and $2 \mathrm{~m}$ from the left vine stock, the difference in the mean values of the two groups was not statistically significant at the $5 \%$ level $(p<0.095$ and $\mathrm{p}<0.103)$. This was due to the fact that the highest values of soil depletion coincided in the same areas for both plots.

\subsection{Soil erosion estimations from botanical benchmarks}

Soil erosion rates were estimated using ISUM, separating the values at the inter 
graft unions (row) from the inter-row values (Table 3). Our results showed that, in the row positions where the measures were conducted at the graft union, lower differences are found compared to the inter-row measures in both studied plots. On the marls plot, a

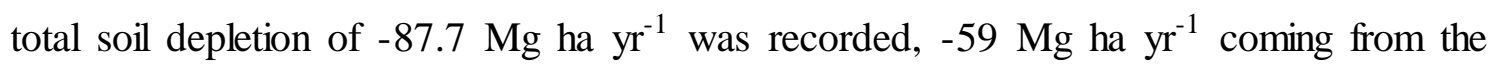
inter-row positions. On the colluvium plot, soil depletion was much lower than on the marls plot. ISUM showed a soil depletion value of $-4.35 \mathrm{Mg}$ ha $\mathrm{yr}^{-1}$, while soil

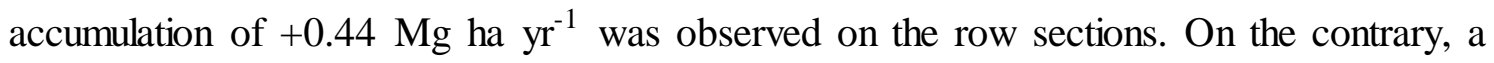
total soil depletion of $-4.79 \mathrm{Mg}$ ha $\mathrm{yr}^{-1}$ was registered in the inter-row areas.

\section{DISCUSSION}

Our findings showed that the changes in topsoil level could also be influenced by the age of plantations and the parent material. Future research should address the magnitude each of these factors plays compared with the well-established factors such as local slope, rainfall intensity, tillage, and trampling effect, vine vigour, soil properties or antecedent soil moisture (Biddoccu et al., 2017a; Novara et al., 2018).

The ISUM was easily applied and generated a fairly accurate data that enhanced a better evaluation of the soil erosion processes at the pedon scale. Moreover, ISUM may be an easily reproducible tool which can generate the production of an actual DEM without drones or planes. In comparison to traditional SUM, which assumes the interrow areas as a flat surface (Brenot et al., 2008), ISUM allows better estimation of soil erosion rates due to the fact that the soil depletion rates take place mainly along the inter-row areas, where SUM did not measure (Rodrigo-Comino and Cerdà, 2018). ISUM has major strengths against other methods such as Gerlach troughs, pins, or close plots. These other methods can only be applied for time periods lasting up to a few years and are highly dependent on rainfall events (Biddoccu et al., 2016; Novara et al., 
2013). Moreover, they introduce artifacts into the pedological system affecting the soil and measurement qualities (Stroosnijder, 2005). Nevertheless, we also acknowledge some limitations of the method (Rodrigo-Comino and Cerdà, 2018). It is obvious that its accuracy is not the best because it is based on a low resolution (cm vs $\mathrm{mm}$ ) in the field. Also, the general assumption that the graft union is always at the same place may in some cases be violated. Thus, more sampling points in the inter-row areas may be necessary.

Our research confirms that recent vine plantations on marls and colluvium registered more soil erosion in this study compared with that reported in other older vineyards (Corti et al., 2011) or even forested areas (Mathys et al., 2005). Research carried out in the Valencian viticulture area confirmed that the age of the plantation played an important role in soil erosion rates and other hydrological processes (Cerdà et al., 2017; Rodrigo-Comino et al., 2018a). However, our findings showed that, in spite of the age of the plantation (the colluvium vineyard being younger than the marls one), marls showed a higher erodible parent material by 1.2 orders of magnitude, which have not ever been registered for plantations with the same parent material but of different ages (Rodrigo-Comino et al., 2018a). These results also support the findings of Martínez-Hernández et al. (2017) that obtained higher erosion rates in marls than in metamorphic and limestones using rainfall simulations in south-eastern Spain. Also, with rainfall simulations, Cerdà $(1999,2002)$ confirmed similar differences among plots on different parent materials in Mediterranean degraded areas.

ISUM has demonstrated that the recent vine plantations on colluvium soils function as a sink area (little depression) located underneath the vines as the soil losses at the graft unions are very low or negligible. This could be due to the plant cover that minimises raindrop impact, reduces soil surface sealing and runoff generation (Ruiz- 
Colmenero et al., 2013). Moreover, the vines are able to intercept and reallocate the rainfall due to the interception and throughfall (Battany and Grismer, 2000). Splash erosion is also relevant in the redistribution of the particles as the inter-row is a source of particles and the rows act as sinks. However, tillage is a factor that determines the accumulation of sediments underneath the vines (Lieskovský and Kenderessy, 2014). Tilling accumulated soils underneath the vines changes the slope micro-topography and the soil horizon distribution (de Alba Alonso et al., 2006). This was also confirmed using ISUM by Rodrigo-Comino et al., (2018b). They demonstrated that tractor passes can cause a reallocation of sediments, coinciding with a decrease in bulk density and modifying the final micro-topographical assessments.

The ISUM showed that the soil depletion takes place in the inter-row areas. Previous research did not distinguish inter-row and row environments within the vineyards (Brenot et al., 2008; Paroissien et al., 2010; Rodrigo Comino et al., 2016). Therefore, our research contributes to showing the spatial variability within the vineyards at the pedon scale and demonstrates that tillage and the row direction against the general slope direction determine the micro-topography and the reallocation of the soil particles. Therefore, it is important to remark that, in recent vine plantations, parent material could be considered as a second driving factor in comparison to the human management (Vrsic et al., 2011). Future research must focus on determining the magnitude to which parent material can affect soil erosion rates. While it was impossible to compare young vineyards with the same age and different parent material due to lack of data, we encourage other researchers to check this interesting possibility in other viticultural areas where paired-plots of similar age can be found.

This paper focused mainly on the effect of different lithology on soil erosion processes within new vine plantations, and we have demonstrated that the parent 
material could also determine the erosion rate differences. We used micro-topographical measurements and a DEM modelling to confirm this finding. Using DEMs, we could not conclude that soil erosion differences were generated as a consequence of different parent materials, but they allow us to observe the evident micro-topographical differences and intensity of the processes due to the introduction of new plantations. It seems that marls are more susceptible to the detachment of particles by raindrop impact compared with colluvium because colluvium is sandy in nature, develops soil crusts and has rock fragments that decrease soil erosion rates.

The behaviour of the inter-rows serving as sources and the rows of vines as sinks of sediments was more evident in the colluvium plot. While most of the sections in the marls study plot showed intense erosion features, soil detachment was more active as the measurements with the ISUM demonstrated. We cannot exclude that the difference of age of these plantations (6 years) can play an important role, but we confirmed that the effect of the age of plantation is not the unique factor acting on soil erodibility.

Our research demonstrates that restoration and rehabilitation programs in vineyards should focus on recent plantations where soil erosion rates are very high.

Previous numerous researches in cultivated areas demonstrated that the use of vegetation cover could reduce the soil erosion rates by one order of magnitude. However, we highlight that these measures must be taken within a few years after the plantation is initially developed, rather than after several years.

\section{CONCLUSIONS}

Soil erosion in vineyards is affected by several natural and anthropogenic driving factors. Thus, we applied ISUM, which is an efficient method to determine soil erosion 
rates taking into account a specific driving factor of age. In this case, the possible influence of the age of plantations on soil erosion on different parent material was determined and quantified. Our results showed that vineyards on marls resulted in a total soil depletion of $87.7 \mathrm{Mg} \mathrm{ha}^{-1} \mathrm{yr}^{-1}$ and those on colluvium materials reached 4.35 $\mathrm{Mg} \mathrm{ha}^{-1} \mathrm{yr}^{-1}$. By using the ISUM, the main source of sediments was found to be from the inter-row areas where there is no vegetation cover. This behaviour of the inter-rows as sources and the rows of vines as sinks of sediments was more evident on the colluvium plot, while most of the sections in the marl study plot showed intense erosion features, and the soil detachment was more active. Thus, we would like to highlight that soil erosion control measures must be taken soon after the plantation is first developed instead of waiting several years when the negative consequences such as loss of fertility and productivity have taken place.

\section{AKNOWLEDGEMENTS}

We acknowledge the vineyard's owners Pablo Calatayud and José Molla for providing access to the study area. The first author, J. Rodrigo-Comino, was issued with a grant for this study under the framework of a short-term scientific mission (COST-STSMECOST-STSM-ES1306-010217-081877). We also thank the Bachelor degree and Ph.D. students: Carlos Atienza, Alberto Belenguer, Jorge García Jiménez, José Vicente Vega, Beatriz Stambuck, Jason Davis and Asmare Wubet for the time, efforts and hard work during the field campaign. Constructive comments by the reviewers are gratefully acknowledged. 


\section{REFERENCES}

Anderson, D.W., 1988. The effect of parent material and soil development on nutrient cycling in temperate ecosystems. Biogeochemistry 5, 71-97. doi:10.1007/BF02180318

Arnaez, J., Lasanta, T., Ruiz-Flaño, P., Ortigosa, L., 2007. Factors affecting runoff and erosion under simulated rainfall in Mediterranean vineyards. Soil Tillage Res. 93, 324-334. doi:10.1016/j.still.2006.05.013

Atucha, A., Merwin, I.A., Brown, M.G., Gardiazabal, F., Mena, F., Adriazola, C., Goebel, M., Bauerle, T., 2013. Root distribution and demography in an avocado (Persea americana) orchard under groundcover management systems. Funct. Plant Biol. 40, 507-515.

Battany, M.C., Grismer, M.E., 2000. Rainfall runoff and erosion in Napa Valley vineyards: effects of slope, cover and surface roughness. Hydrol. Process. 14, 1289-1304. doi:10.1002/(SICI)1099-1085(200005)14:7<1289::AID-HYP43>3.0.CO;2-R

Berland, A., Shiflett, S.A., Shuster, W.D., Garmestani, A.S., Goddard, H.C., Herrmann, D.L., Hopton, M.E., 2017. The role of trees in urban stormwater management. Landsc. Urban Plan. 162, 167-177. doi:10.1016/j. landurbplan.2017.02.017

Biddoccu, M., Ferraris, S., Opsi, F., Cavallo, E., 2016. Long-term monitoring of soil management effects on runoff and soil erosion in sloping vineyards in Alto Monferrato (North-West Italy). Soil Tillage Res. 155, 176-189. doi:10.1016/j.still.2015.07.005

Biddoccu, M., Ferraris, S., Pitacco, A., Cavallo, E., 2017a. Temporal variability of soil management effects on soil hydrological properties, runoff and erosion at the field scale in a hillslope vineyard, North-West Italy. Soil Tillage Res. 165, 46-58. doi: 10.1016/j.still.2016.07.017

Biddoccu, M., Zecca, O., Audisio, C., Godone, F., Barmaz, A., Cavallo, E., 2017b. Assessment of long-term soil erosion in a mountain vineyard, Aosta Valley (NW Italy). Land Degrad. Dev. doi:10.1002/ldr.2657

Braithwaite, L.W., Turner, J., Kelly, J., 1984. Studies on the Arboreal Marsupial Fauna of Eucalypt Forests Being Harvested for Wood Pulp at Eden, NSW Iii. Relationships Between Faunal Densities, Eucalypt Occurrence and Foliage Nutrients, and Soil Parent Materials. Wildl. Res. 11, 41-48. doi:10.1071/wr9840041

Brenot, J., Quiquerez, A., Petit, C., Garcia, J.-P., 2008. Erosion rates and sediment budgets in vineyards at $1-\mathrm{m}$ resolution based on stock unearthing (Burgundy, France). Geomorphology 100, 345-355. doi:10.1016/j.geomorph.2008.01.005

Brenot, J., Quiquerez, A., Petit, C., Garcia, J.-P., Davy, P., 2006. Soil erosion rates in Burgundian vineyards. Boll. Della Soc. Geol. Ital. 6, 169-173.

Brimhall, G.H., Christopher J., L., Ford, C., Bratt, J., Taylor, G., Warin, O., 1991. Quantitative geochemical approach to pedogenesis: importance of parent material reduction, volumetric expansion, and eolian influx in lateritization. Geoderma, Weathering of soils 51, 51-91. doi:10.1016/0016-7061(91)90066-3

Bryan, R.B., 2000. Soil erodibility and processes of water erosion on hillslope. Geomorphology 32, 385-415. doi:10.1016/S0169-555X(99)00105-1

Bryan, R.B., Govers, G., Poesen, J., 1989. The concept of soil erodibility and some problems of assessment and application. Catena 16,393-412. doi:10.1016/0341-8162(89)90023-4

Casalí, J., Giménez, R., De Santisteban, L., Álvarez-Mozos, J., Mena, J., Del Valle de Lersundi, J., 2009. Determination of long-term erosion rates in vineyards of Navarre (Spain) using botanical benchmarks. Catena 78, 12-19. doi:10.1016/j.catena.2009.02.015

Castillo, F.E., Ruiz Beltrán, L., 1979. Precipitaciones máximas en España. M. ${ }^{\circ}$ de Agricultura, Madrid, Spain.

Cattanio, J.H., 2017. Leaf area index and root biomass variation at different secondary forest ages in the eastern Amazon. For. Ecol. Manag. 400, 1-11. doi:10.1016/j.foreco.2017.05.033

Cerdà, A., 1999. Parent material and vegetation affect soil erosion in Eastern Spain. Soil Sci. Soc. Am. J. 63. doi:10.2136/sssaj1999.03615995006300020014x 
Cerdà, A., 2002. The effect of season and parent material on water erosion on highly eroded soils in eastern Spain. J. Arid Environ. 52, 319-337. doi:10.1006/jare.2002.1009

Cerdà, A., Keesstra, S.D., Rodrigo-Comino, J., Novara, A., Pereira, P., Brevik, E., GiménezMorera, A., Fernández-Raga, M., Pulido, M., di Prima, S., Jordán, A., 2017. Runoff initiation, soil detachment and connectivity are enhanced as a consequence of vineyards plantations. J. Environ. Manage. 202, 268-275. doi :10.1016/j.jenvman.2017.07.036

Chesworth, W., 1973. The parent rock effect in the genesis of soil. Geoderma 10, 215-225. doi:10.1016/0016-7061(73)90064-5

Corti, G., Cavallo, E., Cocco, S., Biddoccu, M., Brecciaroli, G., Agnelli, A., 2011. Evaluation of Erosion Intensity and Some of Its Consequences in Vineyards from Two Hilly Environments Under a Mediterranean Type of Climate, Italy. doi: 10.5772/25130

Dawson, L., Elbakidze, M., Angelstam, P., Gordon, J., 2017. Governance and management dynamics of landscape restoration at multiple scales: Learning from successful environmental managers in Sweden. J. Environ. Manage. 197, 24-40. doi:10.1016/j.jenvman.2017.03.019

De Alba Alonso, S., Borselli, L., Torri, D., Pellegrini, S., Bazzoffi, P., 2006. Assessment of tillage erosion by mouldboard plough in Tuscany (Italy). Soil Tillage Res. 85, 123-142. doi:10.1016/j.still.2004.12.002

Driese, S.G., Jacobs, J.R., Nordt, L.C., 2003. Comparison of modern and ancient Vertisols developed on limestone in terms of their geochemistry and parent material. Sediment. Geol. 157, 49-69. doi:10.1016/S0037-0738(02)00194-X

Duchaufour, P., 1997. Abrege de pedologie. Sol, végétation, environnement, 5th ed. Elsevier Masson, Paris, France.

Fitzpatrick, E.A., 1980. Soils: Their Formation, Classification and Distribution. Longman, London, UK.

Foltz, R.B., Elliot, W.J., Wagenbrenner, N.S., 2011. Soil erosion model predictions using parent material/soil texture-based parameters compared to using site-specific parameters. Trans. ASABE 54, 1347-1356. doi:10.13031/2013.39036

García-Díaz, A., Marqués, M.J., Sastre, B., Bienes, R., 2017. Labile and stable soil organic carbon and physical improvements using groundcovers in vineyards from central Spain. Sci. Total Environ. 621, 387-397. https://doi.org/10.1016/j.scitotenv.2017.11.240

IUSS Working Group WRB, 2014. World Reference Base for Soil Resources 2014, World Soil Resources Report. FAO, Rome.

Lieskovský, J., Kenderessy, P., 2014. Modelling the effect of vegetation cover and different tillage practices on soil erosion in vineyards: a case study in Vráble (Slovakia) using WATEM/SEDEM. Land Degrad. Dev. 25, 288-296. doi:10.1002/ldr.2162

Lombardi, F., Scippa, G.S., Lasserre, B., Montagnoli, A., Tognetti, R., Marchetti, M., Chiatante, D., 2017. The influence of slope on Spartium junceum root system: morphological, anatomical and biomechanical adaptation. J. Plant Res. doi:10.1007/s10265-017-0919-3

Marques, M.J., Bienes, R., Cuadrado, J., Ruiz-Colmenero, M., Barbero-Sierra, C., Velasco, A., 2015. Analysing perceptions attitudes and responses of winegrowers about sustainable land management in Central Spain. Land Degrad. Dev. 26, 458-467. doi: $10.1002 / \mathrm{ldr} .2355$

Martínez-Casasnovas, J.A., Ramos, M.C., Cots-Folch, R., 2010. Influence of the EU CAP on terrain morphology and vineyard cultivation in the Priorat region of NE Spain. Land Use Policy 27, 11-21. doi: 10.1016/j.landusepol.2008.01.009

Martínez-Casasnovas, J.A., Ramos, M.C., García-Hernández, D., 2009. Effects of land-use changes in vegetation cover and sidewall erosion in a gully head of the Penedès region (northeast Spain). Earth Surf. Process. Landf. 34, 1927-1937. doi:10.1002/esp.1870

Martínez-Hernández, C., Rodrigo-Comino, J., Romero-Díaz, A., 2017. Impact of lithology and soil properties on abandoned dryland terraces during the early stages of soil erosion by water in Southeast Spain. Hydrol. Process. In press. doi:10.1002/hyp.11251

Mathys, N., Klotz, S., Esteves, M., Descroix, L., Lapetite, J.M., 2005. Runoff and erosion in the Black Marls of the French Alps: Observations and measurements at the plot scale. Catena, Gully Erosion: A Global Issue 63, 261-281. doi:10.1016/j.catena.2005.06.010 
Mohammadkhan, S., Ahmadi, H., Jafari, M., 2011. Relationship between soil erosion, slope, parent material, and distance to road (Case study: Latian Watershed, Iran). Arab. J. Geosci. 4, 331-338. doi:10.1007/s 12517-010-0197-z

Muhs, D.R., Bettis, E.A., Been, J., McGeehin, J.P., 2001. Impact of Climate and Parent Material on Chemical Weathering in Loess-derived Soils of the Mississippi River Valley. Soil Sci. Soc. Am. J. 65, 1761-1777. doi:10.2136/sssaj2001.1761

Nazari Samani, A., Khosravi, H., Mesbahzadeh, T., Azarakhshi, M., Rahdari, M.R., 2016. Determination of sand dune characteristics through geomorphometry and wind data analysis in central Iran (Kashan Erg). Arab. J. Geosci. 9, 716. https://doi.org/10.1007/s12517-016-2746-6

Novara, A., Gristina, L., Guaitoli, F., Santoro, A., Cerdà, A., 2013. Managing soil nitrate with cover crops and buffer strips in Sicilian vineyards. Solid Earth 4, 255-262. doi:10.5194/se-4-255-2013

Novara, A., Pisciotta, A., Minacapilli, M., Maltese, A., Capodici, F., Cerdà, A., Gristina, L., 2018. The impact of soil erosion on soil fertility and vine vigor. A multidisciplinary approach based on field, laboratory and remote sensing approaches. Sci. Total Environ. 622-623, 474-480. doi.org/10.1016/j.scitotenv.2017.11.272

Orgill, S.E., Condon, J.R., Conyers, M.K., Morris, S.G., Murphy, B.W., Greene, R.S.B., 2017. Parent material and climate affect soil organic carbon fractions under pastures in southeastern Australia. Soil Res. doi:10.1071/SR16305

Osher, L.J., Buol, S.W., 1998. Relationship of soil properties to parent material and landscape position in eastern Madre de Dios, Peru. Geoderma 83, 143-166. doi:10.1016/S00167061(97)00133-X

Paroissien, J.-B., Lagacherie, P., Le Bissonnais, Y., 2010. A regional-scale study of multidecennial erosion of vineyard fields using vine-stock unearthing-burying measurements. Catena 82, 159-168. doi:10.1016/j.catena.2010.06.002

Pennock, D.J., Jong, E. de, Lemmen, D.S., 1995. Cesium-137-measured erosion rates for soils of five parent-material groups in southwestern Saskatchewan. Can. J. Soil Sci. 75, 205210. doi: $10.4141 /$ cjss $95-028$

Quiquerez, A., Brenot, J., Garcia, J.-P., Petit, C., 2008. Soil degradation caused by a highintensity rainfall event: Implications for medium-term soil sustainability in Burgundian vineyards. Catena 73, 89-97. https $/ /$ doi.org/10.1016/j.catena.2007.0

Ramos, M.C., Porta, J., 1997. Analysis of design criteria for vineyard terraces in the mediterranean area of North East Spain. Soil Technol. 10, 155-166. doi: 10.1016/S0933-3630(96)00006-2

Rawlins, B.G., Webster, R., Lister, T.R., 2003. The influence of parent material on topsoil geochemistry in eastern England. Earth Surf. Process. Landf. 28, 1389-1409. doi:10.1002/esp.507

Rodrigo Comino, J., Quiquerez, A., Follain, S., Raclot, D., Le Bissonnais, Y., Casalí, J., Giménez, R., Cerdà, A., Keesstra, S.D., Brevik, E.C., Pereira, P., Senciales, J.M., Seeger, M., Ruiz Sinoga, J.D., Ries, J.B., 2016. Soil erosion in sloping vineyards assessed by using botanical indicators and sediment collectors in the Ruwer-Mosel valley. Agric. Ecosyst. Environ. 233, 158-170. https://doi.org/10.1016/j.agee.2016.09.009

Rodrigo-Comino, J., Cerdà, A., 2018. Improving stock unearthing method to measure soil erosion rates in vineyards. Ecol. Indic. 85, 509-517. https://doi.org/10.1016/j.ecolind.2017.10.042

Rodrigo-Comino, J., Brevik, E.C., Cerdà, A., 2018a. The age of vines as a controlling factor of soil erosion processes in Mediterranean vineyards. Sci. Total Environ. 616-617, 11631173. doi: 10.1016/j.scitotenv.2017.10.204

Rodrigo-Comino, J., Davis, J., Keesstra, S.D., Cerdà, A., 2018b. Updated Measurements in Vineyards Improves Accuracy of Soil Erosion Rates. Agron. J. 110, 411-417. doi:10.2134/agronj2017.07.0414 
Ruiz-Colmenero, M., Bienes, R., Eldridge, D.J., Marques, M.J., 2013. Vegetation cover reduces erosion and enhances soil organic carbon in a vineyard in the central Spain. Catena 104, 153-160. doi:10.1016/j.catena.2012.11.007

Salomé, C., Coll, P., Lardo, E., Metay, A., Villenave, C., Marsden, C., Blanchart, E., Hinsinger, P., Le Cadre, E., 2016. The soil quality concept as a framework to assess management practices in vulnerable agroecosystems: A case study in Mediterranean vineyards. Ecol. Indic. 61, Part 2, 456-465. doi:10.1016/j.ecolind.2015.09.047

Sofia, G., Tarolli, P., 2017. Hydrological response to $\sim 30$ years of agricultural surface water management. Land 6, 3. doi: 10.3390/land6010003

Stroosnijder, L., 2005. Measurement of erosion: Is it possible? CATENA, 25 Years of Assessment of Erosion 64, 162-173. doi:10.1016/j.catena.2005.08.004

Ulrich, A., Becker, R., 2006. Soil parent material is a key determinant of the bacterial community structure in arable soils. FEMS Microbiol. Ecol. 56, 430-443. doi:10.1111/j.1574-6941.2006.00085.x

Vaudour, E., 2002. The Quality of Grapes and Wine in Relation to Geography: Notions of Terroir at Various Scales. J. Wine Res. 13, 117-141. doi:10.1080/0957126022000017981

Vaudour, E., Costantini, E., Jones, G.V., Mocali, S., 2015. An overview of the recent approaches to terroir functional modelling, footprinting and zoning. SOIL 1, 287-312. doi:10.5194/soil-1-287-2015

Vrsic, S., Ivancic, A., Pulko, B., Valdhuber, J., 2011. Effect of soil management systems on erosion and nutrition loss in vineyards on steep slopes. J Environ Biol 32, 289-294.

Wagai, R., Mayer, L.M., Kitayama, K., Knicker, H., 2008. Climate and parent material controls on organic matter storage in surface soils: A three-pool, density-separation approach. Geoderma 147, 23-33. doi:10.1016/j.geoderma.2008.07.010

Weaver, A. van B., 1991. The distribution of soil erosion as a function of slope aspect and parent material in Ciskei, Southern Africa. GeoJournal 23, 29-34. doi:10.1007/BF00204406

Yavitt, J.B., 2000. Nutrient Dynamics of Soil Derived from Different Parent Material on Barro Colorado Island, Panama. Biotropica 32, 198-207. doi:10.1646/00063606(2000)032[0198:NDOSDF]2.0.CO;2

Yesilonis, I.D., Pouyat, R.V., Neerchal, N.K., 2008. Spatial distribution of metals in soils in Baltimore, Maryland: Role of native parent material, proximity to major roads, housing age and screening guidelines. Environ. Pollut. 156, 723-731. doi:10.1016/j.envpol.2008.06.010 


\section{List of tables:}

Table 1 . The properties of the soils at the study area

Table 2. Pairwise multiple comparison procedures of the Mann-Whitney Rank Sum Test.

Table 3. Soil erosion estimation and comparison between the row (inter graft unions) and inter-row areas. 


\section{List of figures}

Figure 1. Study area.

Figure 2. Boxplots of the measured data at the 5 sampling locations along the cross sections of the opposite pair graft unions for the colluvium and the marls plots, the dotted lines are cross sectional sampling point averages; the ends of the boxes are the $5^{\text {th }}$ and $95^{\text {th }}$ percentiles and the median is the continuous line inside the boxes.

Figure 3. ISUM maps of (a) colluvium and (b) marls; the arrow indicates the inclination direction; the orange and yellow strips labeled 1 to 77 are the vine rows selected for the study. 

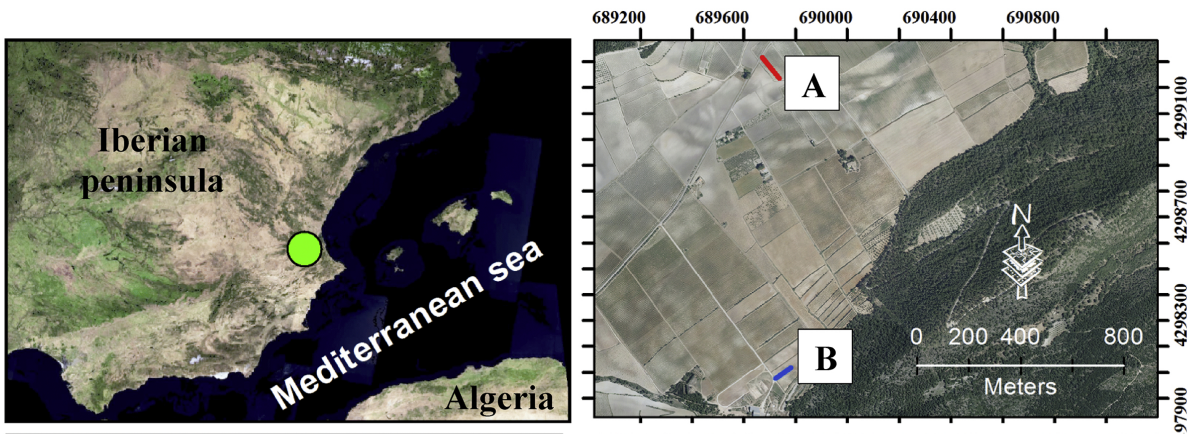

(A) Marls (8 years)

(B) Colluvium (2 years)
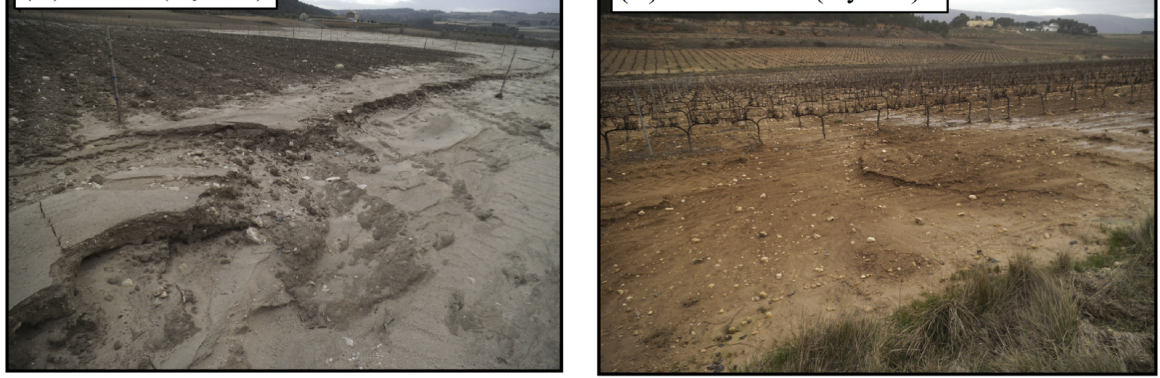

Figure 1 

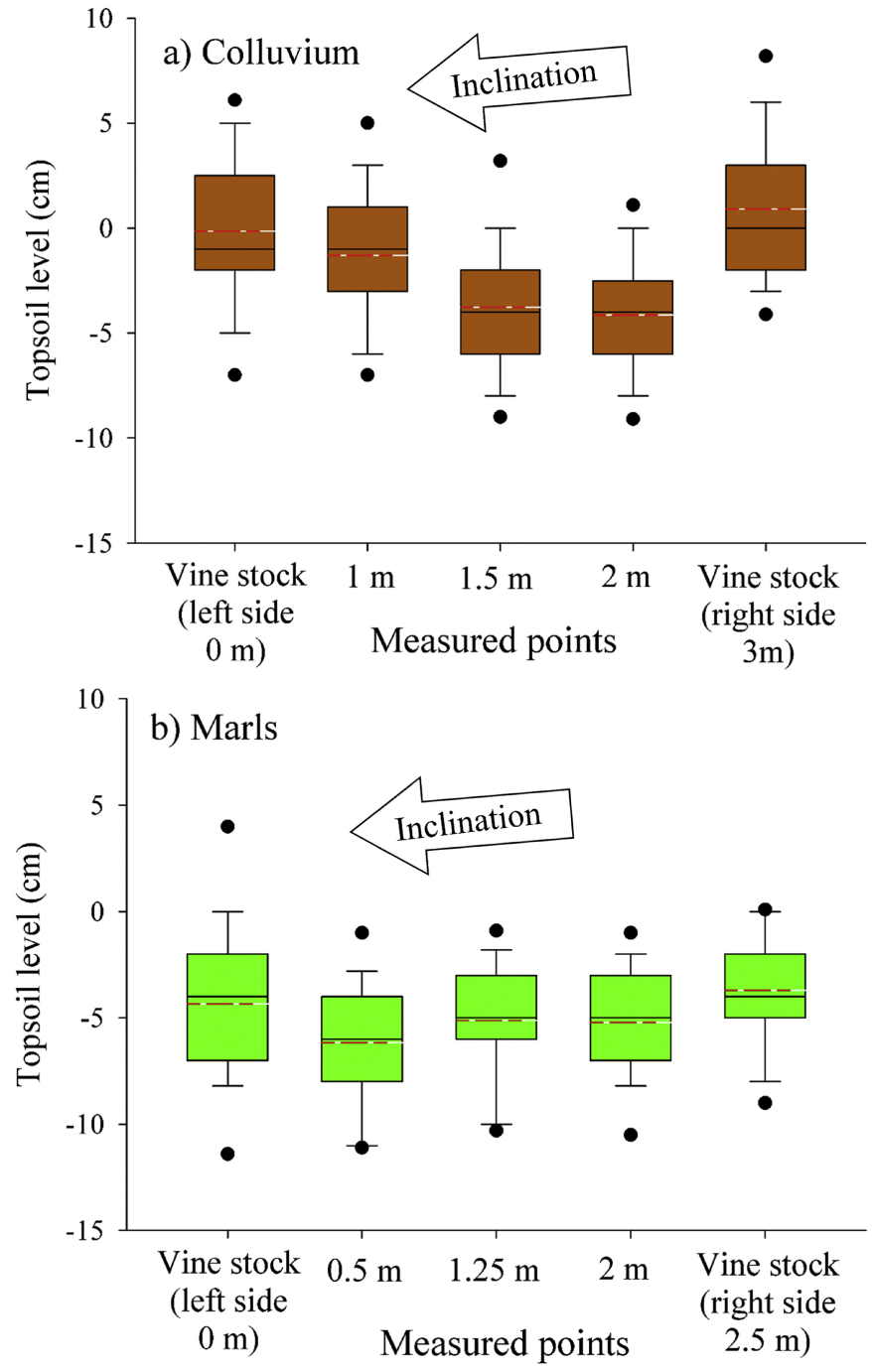

Figure 2 


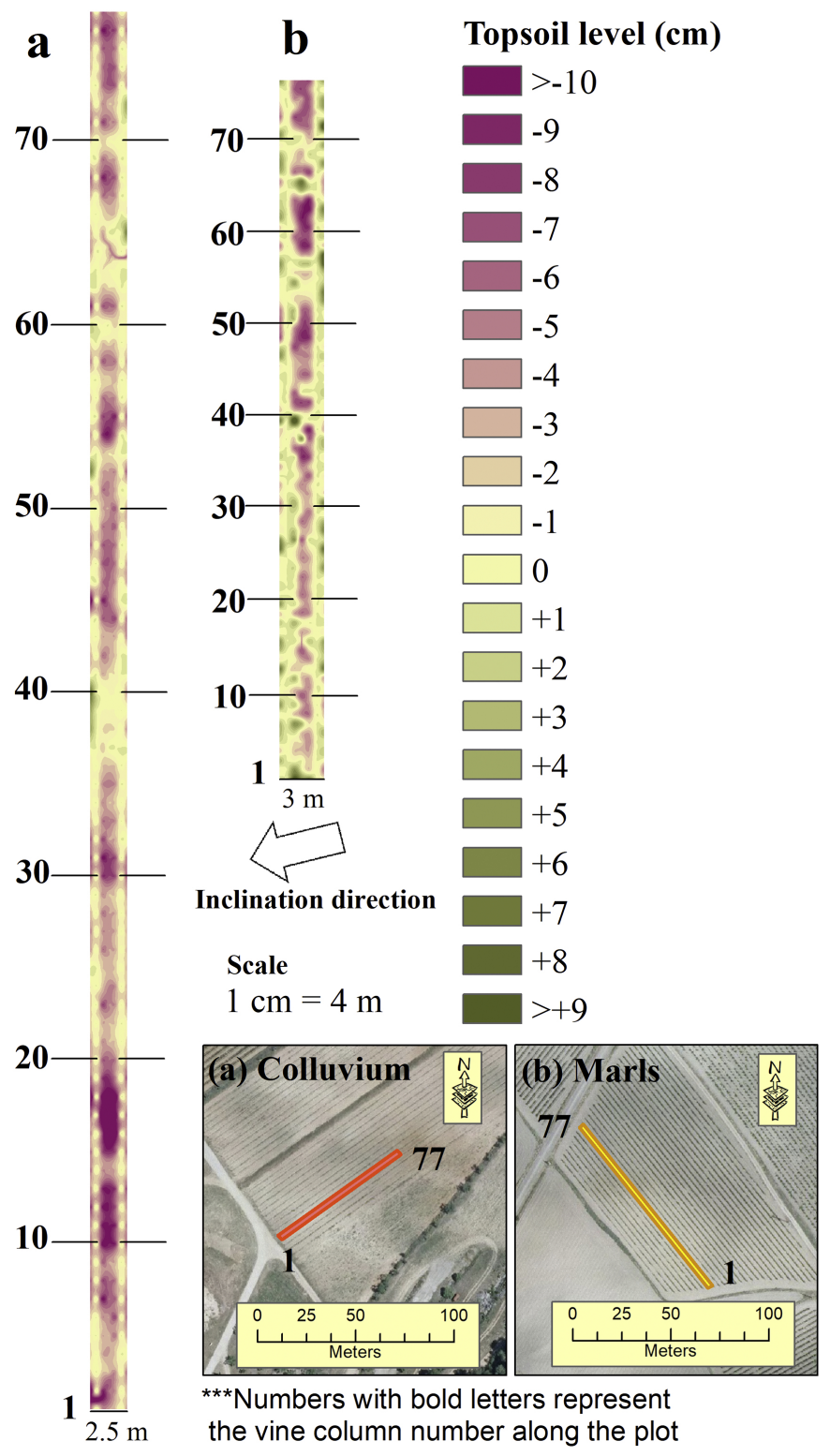

Figure 3 